\title{
REVIEW
}

\section{Environmental effects of the COVID-19 pandemic from a (marine) ecological perspective}

\author{
Marta Coll* \\ Institute of Marine Science (ICM-CSIC), Passeig Marítim de la Barceloneta, no. 37-49, Barcelona 08003, Spain
}

\begin{abstract}
The 2019-2020 pandemic of the SARS-CoV-2 virus - the cause of the novel COVID-19 disease - is an exceptional moment in modern human history. The abrupt and intense cessation of human activities in the first months of the pandemic, when large parts of the global human population were in lockdown, had noticeable effects on the environment that can serve to identify key learning experiences to foster a deep reflection on the human relationship with nature, and their interdependence. There are precious lessons to be learned. A global, tangible threat was needed to trigger a global lockdown, where different societies adopted different strategies and management measures to adapt or transform their activities. Humanity is still coming to terms with how to relaunch the economy while preventing further outbreaks. Here, I summarize the immediate positive and negative effects that the pandemic has had on the natural environment, with emphasis on marine ecosystems. I reflect on key lessons learned from this unprecedented situation so far. The essential role that the oceans play in maintaining the functioning of natural systems and key socio-economic activities is exceptionally relevant, and I discuss key not-to-miss opportunities to add the 'Blue Recovery' to the international agenda under the new 'Build Back Better' or 'Healthy Recovery' context after the acute phase of COVID-19. Achieving sustainable use of the ocean is one of the grand challenges of the new decade, and marine ecologists must play a more proactive role.
\end{abstract}

KEY WORDS: Marine ecology - COVID-19 - Environmental crisis · Climate change · Biodiversity loss $\cdot$ Socio-ecological system $\cdot$ Transformation $\cdot$ Sustainable Development Goals

\section{INTRODUCTION}

During the last days of 2019 and through 2020 (and still at the time of writing), humanity has been immersed in an unprecedented situation due to the 2019-2020 SARS-CoV-2 coronavirus pandemic. This pandemic, also referred to as the COVID-19 pandemic, has forced humanity to face one of its most challenging periods in recent history, with a global reach causing an acute human health crisis with tragic consequences.

In response, governments implemented drastic policies to reduce infections and flatten the curve of

${ }^{*}$ Corresponding author: mcoll@icm.csic.es infection outbreaks. As a result, human activity was considerably reduced in many regions of the world for several consecutive weeks to months. These human confinements may be the largest 'experiment' of abrupt and intense cessations of anthropogenic activities to date, providing a historic snapshot of the effects not only on human well-being but also on the environment and wildlife, including the oceans.

This article aims to highlight observed effects that the COVID-19 pandemic had on the natural environment during the first months of the outbreak, with emphasis on the marine environment, and reflect on

() The author 2020. Open Access under Creative Commons by Attribution Licence. Use, distribution and reproduction are unrestricted. Authors and original publication must be credited. 
the lessons learned from this unprecedented situation. These effects can give us an idea of the magnitude and direction of change that is needed to trigger sustained positive responses from nature. Also, the abrupt nature of the lockdowns provides valuable insights into the negative socio-economic and ecological impacts of such unplanned changes.

Up until 2020, available forecasts and assessments of potential effects of radical cessation of human activities causing large environmental impacts were mostly based on local, or at most regional, case studies or modelling simulations. The COVID-19 pandemic provides a unique opportunity to observe and learn from a real global 'experiment'. Lessons from such an event can be used to evaluate what it should take to face the grandest challenge of our time: adapt and transform our socio-economic systems to be better aligned with our biophysical reality.

\section{THE WORLDWIDE CUMULATIVE EFFECTS OF HUMANS}

During the first weeks of the COVID-19 pandemic, many analyses from well-known scholars appeared, linking the unprecedented event with prior global degradation of nature, which undermines human health and increases the risk of zoonosis (Bates et al. 2020, Corlett et al. 2020, Pearson et al. 2020). In fact, it is globally recognised that human activities have reached a new level of destruction of natural capital, with negative impacts being noticeable worldwide and a large interconnectedness between human sectors and regions (Díaz et al. 2020). These global impacts can be observed on land and at sea (e.g. Estes et al. 2011, Tittensor et al. 2014, Halpern et al. 2015, McCauley et al. 2015, Ceballos et al. 2020).

Human impacts on nature are of such magnitude that the scientific community has established a new geological era to characterise the widespread impact of humans on Earth: the Anthropocene (Lewis \& Maslin 2015). An important element of this new era is the concurrent 'twin environmental crises of our time' (Corlett et al. 2020): a clear change of the Earth's climate and an unprecedented rate of biodiversity loss (Díaz et al. 2019, IPCC 2019), each the focus of the Intergovernmental Panel on Climate Change (IPCC) and the Intergovernmental Science-Policy Platform on Biodiversity and Ecosystem Services (IPBES), respectively, under the auspices of the United Nations. These global and interconnected environmental emergencies pose immense problems to the sustainability of life as we know it, causing unprecedented ecological but also social and economic impacts on human societies and their well-being (Díaz et al. 2019)

Both the climate and the biodiversity crises highlight the fundamental problem of our times: the exploitation of natural resources and the use of ecosystem services is too high and too quick to be sustainable. The global human population has trespassed the boundaries of the global ecosystem and biophysical processes, causing unprecedented shortterm environmental change and increasing the risks of environmental disasters (Rockström et al. 2009a,b). According to the most comprehensive evaluation of human impacts on Earth released in 2019, these impacts have been sharply increasing since the 1970s, with complex and interconnected drivers of economic, social, cultural, demographic, political, institutional and technological origin (Díaz et al. 2019).

Marine ecosystems are not being spared here. Direct drivers that change the marine realm include intense pressure of fishing and aquaculture, loss of coastal and marine habitat, increasing pollution, alien species invasions, and climate change impacts such as rising water temperatures, acidification and declining oxygen (Sala et al. 2000, Pauly et al. 2003, Lotze et al. 2006, Worm et al. 2006, Poloczanska et al. 2013, Mengerink et al. 2014, Levin \& Le Bris 2015, McCauley et al. 2015, Ramírez et al. 2017, Halpern et al. 2019, FAO 2020b). These direct drivers are tightly linked to how human activities are managed and how regulations are socially accepted, enforced and complied with (Mora et al. 2009, Coll et al. 2013, Bundy et al. 2017).

Heterodox currents of economic theory have been warning about the dislodgement of economics and socio-ecologic dynamics as underpinned by mainstream economic theory, and have singled out the relentless pursuit of unlimited growth, production and consumption as being at the base of global environmental problems (Leach et al. 2013, Raworth 2017, Otero et al. 2020). Many international organizations and renowned experts have expressed their concern that unchecked continuation of 'business as usual' may lead to unacceptable risks for present and future generations (IPCC 2018, Díaz et al. 2020, Trisos et al. 2020). Biodiversity loss and ecosystem degradation, both terrestrial and marine, are identified as 2 of the top 5 risks to the global economy, according to the World Economic Forum (WEF) and the IPBES Global Assessment Report (Diaz et al. 2019). Recent global ensemble projections of marine ecosystem models have predicted important declines of marine animal biomass under future scenarios of climate change 
(Lotze et al. 2019) in agreement with historical observations (Free et al. 2019), while the observed increase in frequency and magnitude of extreme events, such as marine heatwaves, are a matter of growing concern (Schewe et al. 2019, Smale et al. 2019).

The impacts of current environmental degradation are widely heterogenic (Halpern et al. 2008, 2012, Dodds et al. 2013, Krausmann et al. 2013) and notably impact the most vulnerable societies (Dearing et al. 2014, O'Neill et al. 2018). This means that those human populations who are most exposed to environmental crises, and that may suffer the most in the future, are not necessarily those who contributed the greatest to their causation (Díaz et al. 2019).

\section{THE SARS-COV-2 PANDEMIC AND ITS SOCIO-ECONOMIC IMPACTS}

The pandemic caused by the new coronavirus SARS-CoV-2 has put entire countries and regions in lockdown, with a first assessment of 4.6 billion people confined by early April 2020 (Bates et al. 2020, Diffenbaugh et al. 2020). The SARS-CoV-2 virus was officially detected in December 2019 in Wuhan, China, and on 30 January 2020, the World Health Organization (WHO) declared the outbreak as a 'Public Health Emergency of International Concern'. Six months later, more than 10000000 cases of COVID-19 were officially reported in 216 countries and territories, resulting in more than 500000 human deaths (WHO, https://covid19.who.int/). As of September 2020, the human cost of the pandemic continues to mount, with more than 29000000 cases confirmed globally and approximately 920000 people known to have died.

The exact origin of the SARS-CoV-2 is still unknown, despite increasing evidence that points to an origin in wildlife (Cyranoski 2020, Wei 2020, Zhang et al. 2020). Experts in emerging infectious diseases have previously warned that habitat fragmentation and degradation, live animal markets, the global trade in wildlife and the degradation of biodiversity all contribute to the increasing risk of diseases spilling over from wildlife into human populations due to shortened connectivity pathways (Sokolow et al. 2019, Doughty et al. 2020, Huong et al. 2020). According to the World Organization for Animal Health, $60 \%$ of known human diseases have originated in animals (https://www.oie.int/). The emergence of new viral diseases in recent time-HIV, Ebola, Nipah, SARS, H5N1 and others - have been attributed, at least in part, to increased human impacts on natural systems (Corlett et al. 2020). A recent study suggested that reduced pathogen dispersal following megafauna extinctions may have increased the emergence of zoonotic pathogens moving into human populations (Doughty et al. 2020).

The lockdowns of entire populations for a sustained period of time, ranging from weeks to months, implied cancellation of most industrial, educational, political, cultural, religious and sporting activities, and a widespread reduction in human movement. The economic impacts of the global coronavirus expansion and virulence are evident worldwide, with losses in jobs, incomes and markets (WEF 2020), provoking the greatest global recession since the Great Depression of the 1930s, even larger than the Great Recession of the early 2000s. According to the International Energy Agency (IEA), the pandemic is 'a macroeconomic shock that is unprecedented in peacetime' (https://www.iea.org/reports/global-energyreview-2020/context-a-world-in-lockdown). One of the main indicators of societal standstill was the abrupt decline in energy demands. Globally, demand for electricity declined in the first quarter of 2020 by $20-30 \%$, road transport activity declined by $75 \%$, and the number of flights decreased globally by $60 \%$ from January to April 2020 when compared with the same period in 2019, according to the IEA (https://www.iea.org/reports/global-energy-review2020). Changes were recorded in many countries and for different types of activities (Le Quéré et al. 2020). While the full social, economic and physiological impacts are still to be quantified, monetary impact on key sectors such as travel, trade and production industries is likely to be in the billions of USD.

Changes in human activities were also observed at sea, affecting the majority of economic activities based on the ocean. Maritime traffic was strongly reduced, with large economic consequences as more than $80 \%$ of the world's trade goods are transported by sea (IMO, https://business.un.org/en/entities/13). Around $46 \%$ of scheduled departures between Asia and Europe were cancelled during the first months of the Chinese lockdown (February-March), resulting in a significant drop in shipping traffic (European Parliament 2020). The global fishing activity of industrial fleets was down by $6.5 \%$ at the end of April 2020 compared to the same period in 2019 (Global Fishing Watch 2020), which can be corrected to $10 \%$ if calculated from the date that the pandemic was declared. Regionally, fishing activity reductions have varied. As of early April 2020, cumulative fishing activity in China's EEZ was down by nearly $40 \%$ since the Chinese New Year, with approximately 
1.2 million fewer fishing hours. Chinese fishing activity has since recovered (Global Fishing Watch 2020). In Peru, having the world's largest commercial fishery, fishing activity dropped by $80 \%$ (Global Fishing Watch 2020), while Indonesian shark trade was reported to have declined by $70 \%$ (Mongabay 2020). In European waters, many countries with heavy fishing activity (e.g. Spain, Italy) saw their fishing substantially reduced during the lockdown, with reductions up to $50 \%$ or more until late May 2020 when compared to preceding years (Global Fishing Watch 2020, Ortega \& Mascarell 2020). Fig. 1 provides an example of this reduction with a comparative image of fishing activity monitored with the automatic identification system (AIS) from an area located in the northwestern Mediterranean Sea (FAOGFCM Geographical Sub-area GSA06, Spain) during one week in February and in April 2020.

The lockdown resulted in an interruption of local and global demand for seafood (Knight et al. 2020, Ortega \& Mascarell 2020), the most traded food commodity in the world. The low demand due to restaurants and fresh markets closing lowered local prices with a supply that surpassed demand (Ortega \& Mascarell 2020). The impacts of COVID-19 were especially important for small-scale fishing activities (Knight et al. 2020, Ortega \& Mascarell 2020, WWF
2020), which supply half of the demand for seafood and employ $90 \%$ of world's fishers (FAO 2020b). Small-scale fisheries directly rely on local fresh markets and trade activities, which collapsed immediately when the COVID-19 pandemic emerged (FAO 2020a). Despite a noticeable increase in direct sales via the internet, high uncertainties in the food supply and interruptions in the traditional value chain meant that fisheries recoveries depended on the reopening of the HORECA (hotels, restaurants and catering) channel, trade routes and other large-scale activities associated with the consumption of seafood, such as tourism (Ortega \& Mascarell 2020, WWF 2020). Before the pandemic, global fisheries supplied society with $~ 96.4$ million tons of fish, 88\% of which was used for direct consumption. With 38.89 million people engaged in the primary fisheries sector and $\sim 4.56$ million fishing vessels in operation, the industry exported annually USD 164.1 billion (FAO $2020 b)$. Although the full consequences of the reduction in fishing effort during the lockdown are still to be quantified, disrupted local and global value chains of seafood production provide a unique opportunity to understand fisheries interdependencies with other sectors (e.g. tourism, trade, HORECA) ranging from the extraction of seafood to its final consumption, and the direct and indirect impacts of
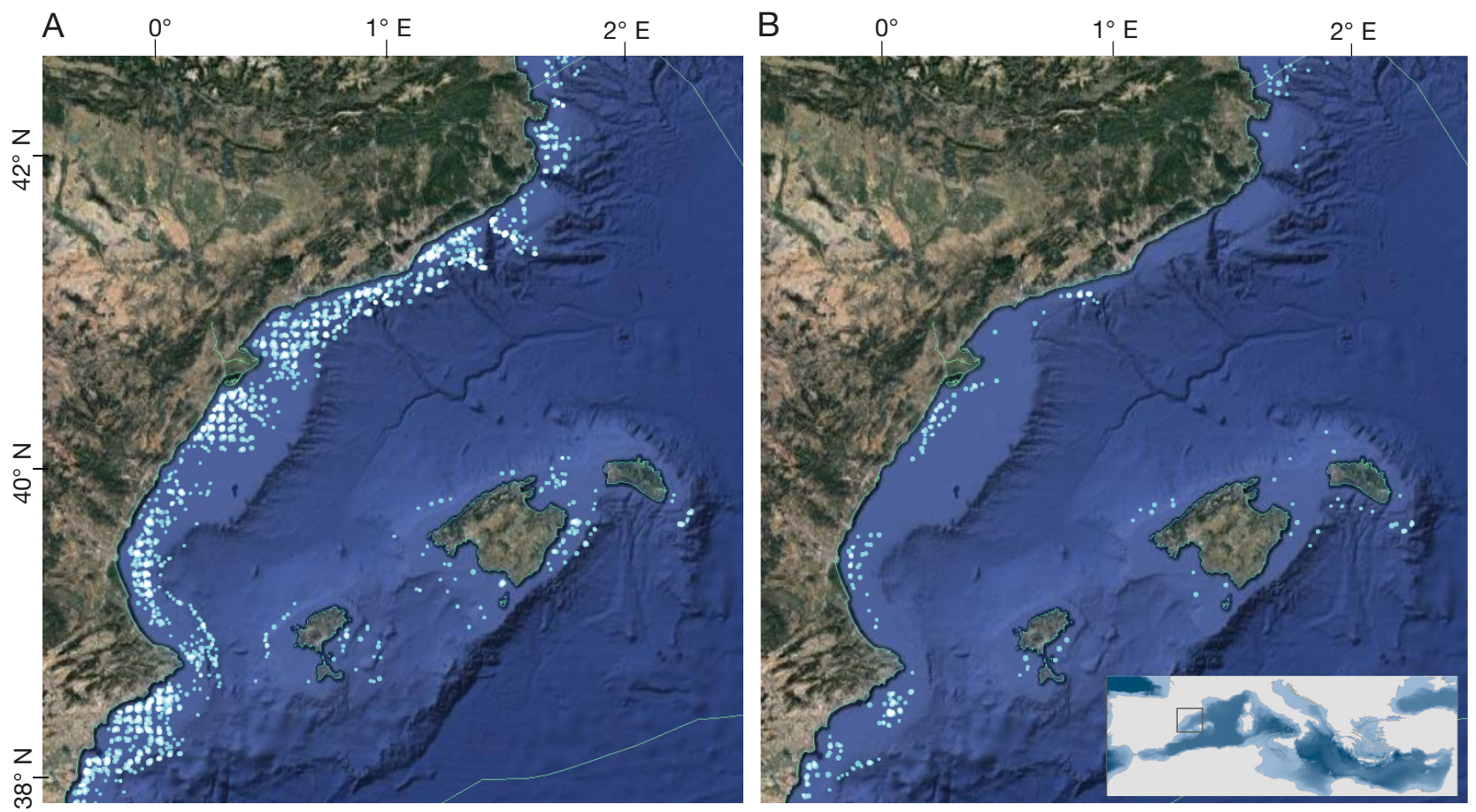

Fig. 1. Comparison of fishing activity in an exploited area of the northwestern Mediterranean coast (Spain) including the Balearic Islands during a week between (A) 26 January to 2 February 2020 and (B) 1 to 7 April 2020 (source: Global Fishing Watch, https://globalfishingwatch.org) 
these interdependencies on marine ecosystems and resources. This understanding can be used to promote market diversification alternatives that may ensure fisheries resilience and sustainability (Knight et al. 2020, Ortega \& Mascarell 2020).

\section{EFFECTS OF THE PANDEMIC ON THE (MARINE) ENVIRONMENT}

There is also increasing evidence that the reductions in human activities have had impacts on the environment (e.g. Saadat et al. 2020). Calls for global collaborative efforts are emerging to provide a comprehensive understanding and quantification of these effects (Bates et al. 2020, Diffenbaugh et al. 2020, Rutz et al. 2020). The first studies mainly reported improved air and water quality, triggered by nearabsence of industrial activity and transportation. Next, news and articles in the media started reporting numerous unusual sightings of wildlife.

Interestingly, one of the first forecasts for the environmental effects of COVID-19 related to the world's $\mathrm{CO}_{2}$ emissions, expected to fall by a maximum of $7-8 \%$ in 2020 depending on the duration of the confinement (Le Quéré et al. 2020). This decline is roughly the equivalent of the annual emission reductions needed to limit global warming to $1.5^{\circ} \mathrm{C}$ above pre-industrial temperatures, in alignment with the Paris Agreements (UN Environmental Programme 2019, Le Quéré et al. 2020). Satellite images also showed dramatic improvements in air quality in countries affected by the pandemic (Corlett et al. 2020, Diffenbaugh et al. 2020). Satellite imagery of nitrogen dioxide concentrations across eastern China between 1-20 January 2020 (before the COVID-19 lockdown) and 10-25 February (during the lockdown) provided some of the first evidence of greenhouse gas reductions. These declines were especially relevant in polluted areas such as big cities (e.g. https:// contaminacio.barcelona/). Another interesting set of seismologic observations reported lower vibrations from 'cultural noise' in big cities during the pandemic (The Guardian 2020a). Reductions in surface transportation not only significantly reduced $\mathrm{CO}_{2}$ emissions and concentrations of nitrogen dioxide, they also caused a measurable drop in seismic vibrations.

A few weeks into the confinement, worldwide media broadcasted sightings of a large variety of wildlife animals that were easier to spot during the COVID-19 pandemic. A preliminary analysis of media releases $(n=121)$ available across the internet from 17 March to 11 June 2020 shows that sightings were most frequently reported in May 2020, followed by April, March and June 2020 (Fig. 2A). Wildlife sightings were widely distributed in many countries (Fig. 2B) and were observed in terrestrial, marine and freshwater ecosystems, with a higher frequency of observations in terrestrial and marine ecosystems (Fig. 2C). Wildlife sightings covered a wide variety of animals, including mammals, birds, reptiles, finfishes and elasmobranchs, invertebrates and plants (Fig. 2D).

Available data show that the consequences of the COVID-19 pandemic lockdown have benefitted marine ecosystems too. Within a few weeks into the confinement, media worldwide broadcasted news related to higher water quality in watersheds, canals, lakes, bays and harbours (Braga et al. 2020). Media reports about wildlife sightings also included marine ecosystems, and preliminary analyses suggest that these reports were of similar frequency to those from terrestrial ecosystems (Figs. 2C \& 3). The sightings were mostly related to highly visible and iconic large marine animals, such as marine mammals including baleen whales, dugongs and manatees, and toothed whales such as orcas and dolphins that appeared in unexpected areas (Figs. 2D \& 3). Seabirds and shoreline birds, elasmobranches and marine turtles followed in importance of reported wildlife sightings. Even smaller organisms such as finfish and invertebrates (with crabs, cephalopods and gastropods mentioned) featured in media highlights (Fig. 3).

The growing interest in wildlife sightings during the core months of the lockdown was clear when analysing Google's search keywords counter (Google Trends, https://trends.google.com/) from 15 December 2019 to 15 June 2020. Keyword trends showed that Google web searches tagged with 'coronavirus and wildlife', 'coronavirus and sighting' and 'coronavirus and animal' started to appear during the third week of January with a peak in popularity in early April 2020 (Fig. 4A). This peak coincides with the highest number of humans under global confinement (Bates et al. 2020, Diffenbaugh et al. 2020). The topic 'coronavirus and sighting' was most popular in the third week of May 2020.

According to Google Trends, the growing interest in marine animal sightings during the COVID-19 pandemic followed those of more general wildlife sightings. Google web searches tagged with 'coronavirus and marine' from the same period appeared during the third week of January 2020 and were most popular from March to late April 2020 (Fig. 4B). The topic 'coronavirus and fishing' followed 2 wk later, and peaked in popularity by early April 2020 (Fig. 4B). By mid-June 2020, both topics were down. 
A) Sightings by month

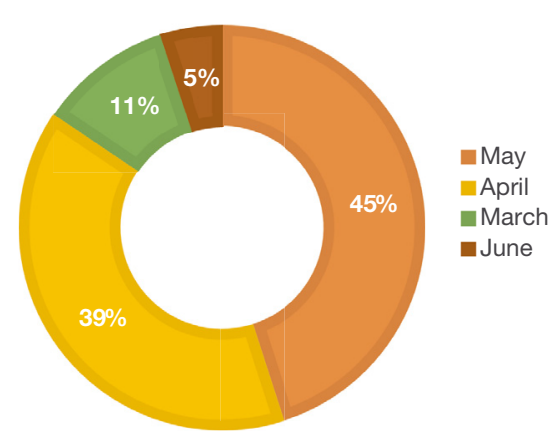

C) Sightings by habitat

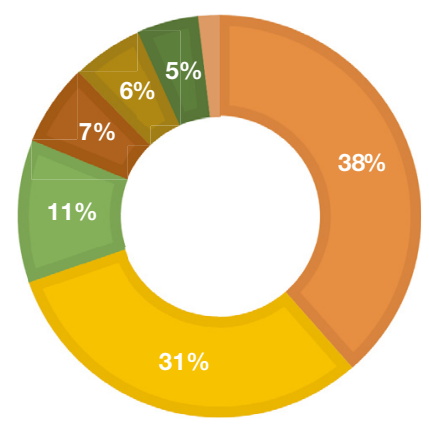

B) Sightings by country

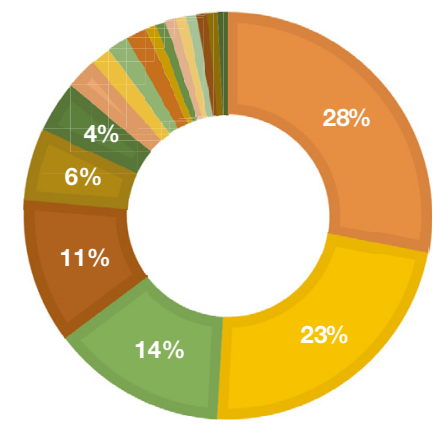

- Various

Spain

- Canada

- USA

India

Thailand

-UK

Bangladesh

Italy

- Japan

Australia

-France

- Indonesia

Kazakhstan

Malta

Mexico

- Pakistan

- Philippines

D) Sightings by marine organisms

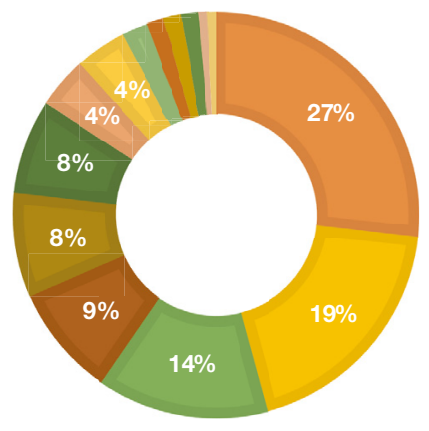

Fig. 2. Non-systematic review of wildlife sightings in online media news worldwide $(\mathrm{n}=121)$ during the COVID-19 pandemic (coverage from 17 March to 11 June 2020): (A) sightings by month, (B) sightings by country, (C) sightings by habitat and (D) sightings by organism type. Values of $2 \%$ or lower are not explicitly identified

Although some wildlife sighting reports may have been fabricated or exaggerated, they indicate that many types of wild organism benefitted from the reduced exposure to people during the pandemic, with field data confirming increases in species richness in temporarily less-disturbed habitats (e.g. Manenti et al. 2020). Similar benefits from reductions in human activities were previously observed in large protected areas or during prolonged episodes of war (Lotze et al. 2011, Duarte et al. 2020), as well as in specific areas such as in the exclusion zones around the Chernobyl and Fukushima nuclear plants and the Demilitarized Zone between North and South Korea (e.g. Lyons et al. 2020, Main 2020). Future studies based on data collected during the lockdown will provide important quantitative insights into human-wildlife interactions and the specific mechanisms behind them (Bates et al. 2020, Rutz et al. 2020).

While the sightings of wildlife during the COVID-19 pandemic do not necessarily mean that there was an absolute increase of wildlife populations, they can be related to a change of distribution and behaviour of animals due to reduced human activity (Bates et al. 2020, Rutz et al. 2020). Plausible explanations for the marine sightings include the reduction in accidental deaths or injuries due to collisions with boats, a reduction in underwater noise and maritime traffic, and the availability of a larger habitat in which to feed or nest. According to the Florida Fish and Wildlife Conservation Commission, by 10 April 2020, the deaths of manatees caused by collisions with boats were down by almost $50 \%$ compared to registrations for the same period in 2019 (FWC 2020). At sea, fishing activities are one of the most important in terms of negative impacts on natural resources, marine biodiversity and ecosystems (Worm et al. 2006, Costello et al. 2012, Coll et al. 2020). The large reductions in fishing effort during the COVID-19 pandemic could be translated into lower fishing mortality for targeted and by-catch organisms, with likely positive (but short-term) consequences on recruitment success, especially for animals with shorter life spans and higher capacity for growth. The ecological effects of such a large reduction in fishing effort in the ocean are still to be fully analysed. 

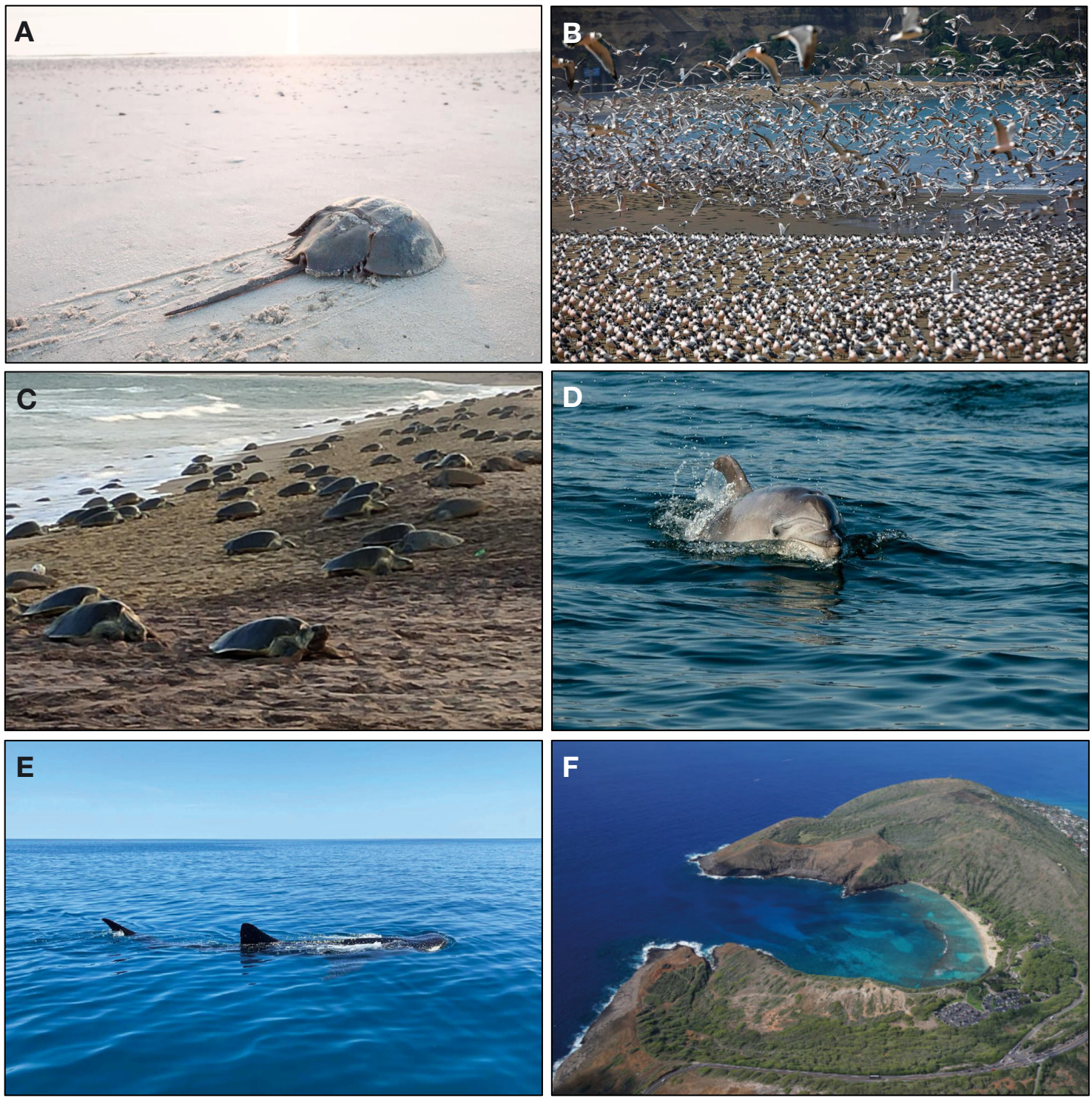

Fig. 3. Examples of marine wildlife sightings in online media between March and June 2020. (A) Horseshoe crab (Limulidae), Delaware Bay, New Jersey, USA. (B) Birds flock in Agua Dulce beach, Lima, Peru. (C) Olive ridley turtles (Lepidochelys olivacea), Rushikulya River Mouth Beach, India. (D) Common bottlenose dolphin (Tursiops truncatus), Bosporus strait, Turkey. (E) Whale shark (Rhincodon typus), Siesta Key, Florida, USA. (F) Coral reef of Hanauma Bay, Hawaii, USA. Sources: (A,C,D) https://www.forbes.com/sites/nishandegnarain/20; (B) https://abcnews.go.com/International/photos-wildlife-roams-planetshuman-population-isolates/story?id=70213431; (E) https://www.clickorlando.com/news/local/2020/05/06/whale-of-a-tale-giantwhale-shark-spotted-off-florida-coast/; and (F) https://www.civilbeat.org/2020/04/the-coronavirus-has-been-good-for-hanaumabay/)

Despite the positive environmental effects, there is much uncertainty about the long-term benefits of the COVID-19 pandemic for the environment (e.g. Bates et al. 2020, Corlett et al. 2020, Diffenbaugh et al. 2020, Freire-González \& Font Vivanco 2020, Gardner 2020, Saadat et al. 2020). For example, while $\mathrm{CO}_{2}$ build-up will be slightly slower than previously expected (IPCC 2019), the reduction is probably not enough to substantially slow global warming (Diffenbaugh et al. 2020).
At the same time, negative environmental impacts of the COVID-19 pandemic clearly emerged. For example, there is growing concern about the surge in consumption and disposal of single-use plastics for individual protection, which poses environmental challenges (Klemeš et al. 2020, Saadat et al. 2020), including in marine ecosystems (Canning-Clode et al. 2020), and there is a risk that governments may lift plastic bans and reduction measures (e.g. Euronews 2020, The 


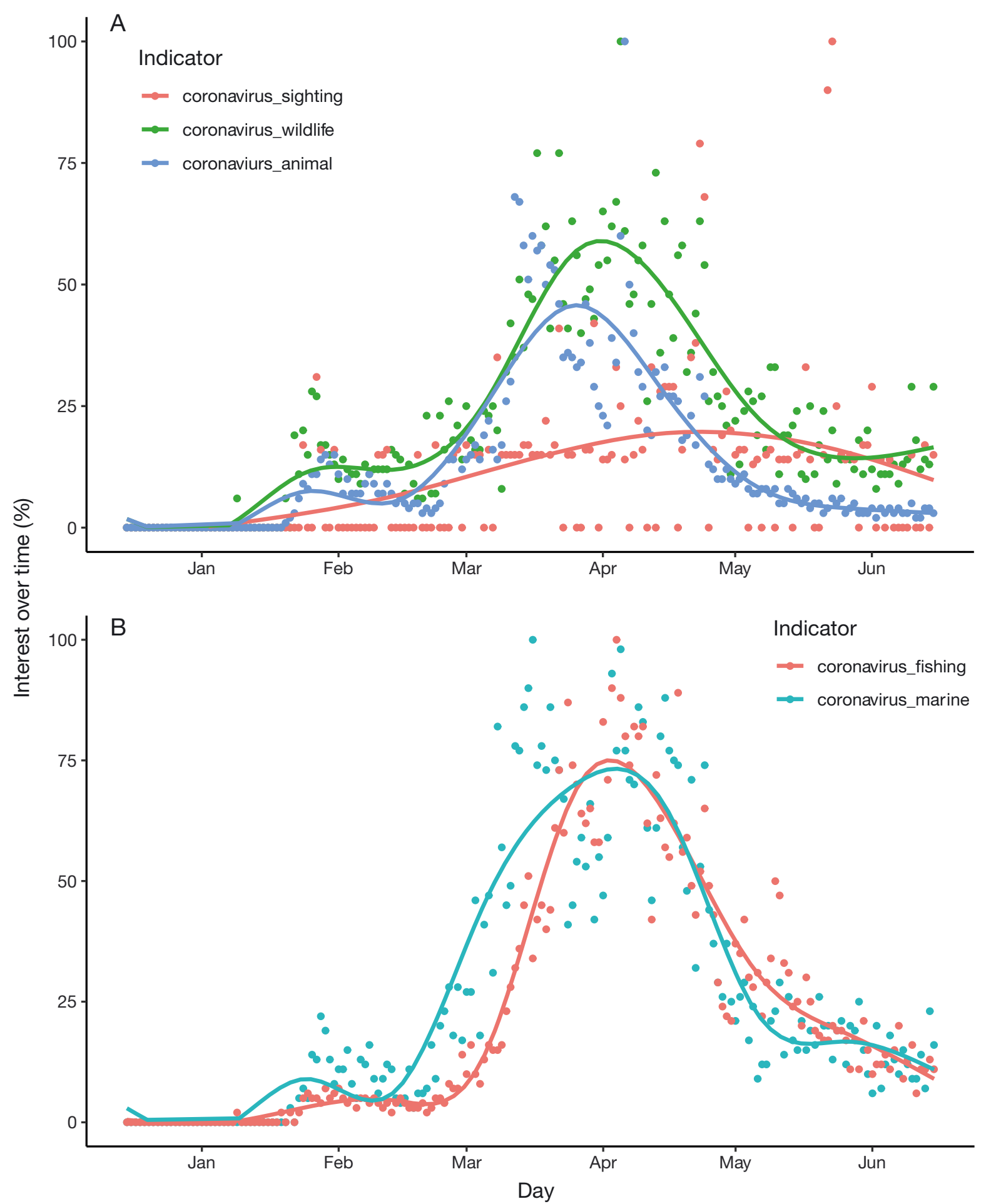

Fig. 4. Temporal trends of interest in web searches about 'coronavirus' and (A) 'sighting', 'wildlife' and 'animal', and (B) 'fishing' and 'marine' from 15 December 2019 to 15 June 2020. Source: Google Trends (https://trends.google.com)

Guardian 2020b, The New York Times 2020). Furthermore, private transport may outpace public transportation out of fear of contagion, which may raise $\mathrm{CO}_{2}$ emissions above pre-pandemic levels (Cohen 2020).
In addition, many environmental enforcement programs, observer programs and monitoring surveys had to be postponed or suspended during the lockdown, on land as well as at sea. This can hamper the 
collection of continuous time series of observations from natural systems, which in turn are fundamental for ecosystem assessment, management and, ultimately, conservation (Bates et al. 2020, Corlett et al. 2020, Manenti et al. 2020). Governments and conservation organizations faced challenges to ensure surveillance, enforcement and management of national parks and natural protected areas during the lockdown, with a reported increase in illegal hunting and poaching (Buckley 2020, Corlett et al. 2020, Gardner 2020, Manenti et al. 2020). In the future, conservation organizations, environmental charities and research institutions may face important losses of income and funding, which may have impacts on their ability to tackle climate change and to halt declines in biodiversity. Furthermore, disproportionally high impacts on early-career scientists are of concern (Pardo et al. 2020), especially from underrepresented or disadvantaged communities, or those discriminated against (Bates et al. 2020, Maas et al. 2020).

\section{KEY LESSONS OF COVID-19 FOR A RESILIENT FUTURE}

The COVID-19 pandemic is the largest 'experiment' of a drastic, global reduction in cumulative human impacts on natural ecosystems in modern history, with very relevant outcomes related to both the climate change and biodiversity loss crises. Although research results and detailed quantifications of direct and indirect socio-economic and ecological impacts are still to come, a few preliminary key points for reflection can be identified.

First, environmental recovery starts quickly. Nature, on land and at sea, reacted notably and quickly to the global reduction in human activities during the first months of the pandemic. The long-term environmental effects and their magnitude will depend on the severity and duration of particular lockdowns and management responses. Future scientific analyses will confirm or dispute the 'coronavirus conservation effects', which will provide invaluable insights into the magnitude and direction of environmental change in response to (temporarily) changed human behaviour.

Second, noticeable recoveries need intense efforts. Noticeable environmental change does not come easy. Major reductions of polluting industrial and transportation activities, combined with a severe reduction of human mobility, were needed earlier in 2020 to have a noticeable impact on nature. This underlines the generalised magnitude and pervasiveness of every-day anthropogenic impacts on the environment and the magnitude of the action needed to curb the negative impacts that humans have on nature worldwide.

Third, a new environmental baseline is available. The effects on nature of the slow-downs or lockdowns that have followed the onset of the COVID-19 pandemic help set a new environmental baseline, and have allowed some people to appreciate vital ecosystem services such as clean air and water. This new environmental baseline may contribute to building a stronger case for behavioural change and to shape new policies that can deliver greener and more sustainable lifestyles. Several studies have already pointed out that many human activities must be transformed to achieve sustainability; the COVID19 pandemic has provided humanity with a firsthand experience of some beneficial consequences of such transformation. This may popularise the realisation that recoveries are possible and can be achieved globally with benefits for many, thus providing additional incentives to instigate societal change towards sustainability.

Fourth, acute social-economic problems follow unplanned cessation of human activities. The abrupt, intense and unplanned cessation of human activities in efforts to curb the COVID-19 pandemic caused a deep economic crisis with devastating impacts on jobs, social interactions and general human wellbeing. While some activities have recovered after the easing of lockdowns, many aspects of our societies that rely on complex and globalised value chains, such as seafood trade, may take longer. Future studies will quantify the total magnitude of these impacts and their lasting direct and indirect effects. In particular, efforts to choose and build a more sustainable future will benefit from in-depth analyses on how responses from different countries, across different political and belief systems, have impacted local populations, recoveries and ecosystems.

Fifth, the socio-economic systems are interlinked with environmental dynamics. The effects of the COVID-19 pandemic on human societies and economies have so far confirmed the need to recognise that thriving human activities are linked and dependent on the health of ecological systems. Reductions in human activities to positively affect natural systems may bring large negative social and economic impacts if they are abrupt, intense and unplanned, as they can deeply disrupt well-established value chains without alternative options.

Sixth, large adaptations and transformations of human activities are needed. Adaptation and transformation of human activities during the COVID-19 
pandemic have occurred worldwide, including farreaching actions at the individual, local, regional and global scales. The pandemic has provided invaluable insights into development of future pathways to adapt and transform human mobility, surface transportation, energy production, global trade and consumption. The mass 'experiment' of COVID-19 provides empirical insights into determining alternative and complementary activities that can be fostered to define a sustainable future while averting or mitigating socio-economic losses, and will enable us to learn from the indirect long-term impacts on the socio-ecological system.

Overall, the current environmental crisis, and the COVID-19 pandemic in particular, underscores the urge to rethink the rate and intensity at which humans exploit natural resources, and how to reshape civilisation, from habits ranging from the individual, local and national to international levels, to urgently achieve sustainable, healthy and fair human societies (Raworth 2017, Díaz et al. 2019). This is definitively a grand challenge for humanity, which has become more urgent than ever. The COVID-19 pandemic, with its exceptionally abrupt and numerous impacts, has brought an unmissable opportunity to take action. Important conclusions can be drawn from the many human activities and management systems that had to adapt or were transformed during the slow-downs and lockdowns. To succeed, humans will need to reconcile the conservation of nature with its rational use and profitability while preventing further environmental degradation. This will necessitate the redefinition of human values and priorities, the identification of trade-offs, and the fair distribution of benefits and costs (Díaz et al. 2019). Clear room for improvement is evident worldwide, where humans face the challenge of achieving a good quality of life for more than 7 billion people without further compromising the biophysical boundaries of our planet $\left(\mathrm{O}^{\prime}\right.$ Neill et al. 2018, O'Neill 2020, Otero et al. 2020).

In this context, it is fundamental to understand, recognise and communicate the dependencies between interlinked human activities and the natural world to achieve the United Nations (UN) Sustainable Development Goals (SDGs) (Griggs et al. 2013, UN 2016). It is essential to recognise that the success of achieving the SDGs related to society (SDGs 1-5, 7 and 11) and the economy (SDGs 8-10 and 12) depends largely on the success of achieving the goals directly linked to the biosphere (SDGs 6 and 13-15) while ensuring peaceful, just and inclusive societies with strong institutions and global partnerships for sustainable development (SDGs 16 and 17) (Fig. 5).
The year 2020 is set for making large decisions about tackling biodiversity conservation and climate-change mitigation over the next decade, which brings a range of opportunities to implement lessons learnt from the COVID-19 pandemic and its impacts. Many current discussions mention the opportunity to 'Build Back Better' or move towards a 'Healthy Recovery' and ensure resilience and resistance of the socio-ecological systems against future crises (Pearson et al. 2020), including the climate change crisis. National and international initiatives calling for a 'green recovery' are widespread and should serve to push for the changes that are needed. The 'European Green Deal' to make the EU's economy more sustainable and the new post-2020 targets of the Convention on Biological Diversity are examples of such emerging initiatives. Future policies should, for example, promote the sustainable and circular economy, push for efficient and innovative technologies, and foster the change of consumption patterns by humans.

Within this context, the role the oceans play in maintaining the functioning of natural systems is exceptionally relevant (Fig. 5). Ocean life plays a crucial role in regulating the Earth's climate and biogeochemical cycles of carbon and other essential elements, contributes to food security and coastal protection, and provides many other goods and services of socio-economical and cultural value to humans. The ocean covers $70 \%$ of planet Earth, produces $50-80 \%$ of the oxygen and contains $97 \%$ of the water available on Earth. Preserving a resilient living ocean is thus a fundamental condition and insurance for a healthy planet, interconnected with healthy land, freshwater and climate systems (Fig. 5), and is the grand marine challenge of the next decade (Claudet et al. 2020). The sustainable use of marine life is essential for the well-being of present and future human generations, as it is clearly recognised by the UN SDG 14 'Life below water' with the statement 'that the world's oceans - their temperature, chemistry, currents and life-drive global systems that make the Earth habitable for humankind (Visbeck et al. 2014). New initiatives such as the 20212030 UN Decade of Ocean Science for Sustainable Development (Claudet et al. 2020) and the UN Decade of Ecosystems Restoration (Young \& Schwartz 2019) are not-to-miss key opportunities to add the 'Blue Recovery' to the international agenda. This is especially necessary after the realization that, as 2020 is coming to an end, it is now clear that the 'good environmental status' envisaged by the EU Marine Strategy Framework Directive will not be achieved (EU 2008), and the Aichi Biodiversity 


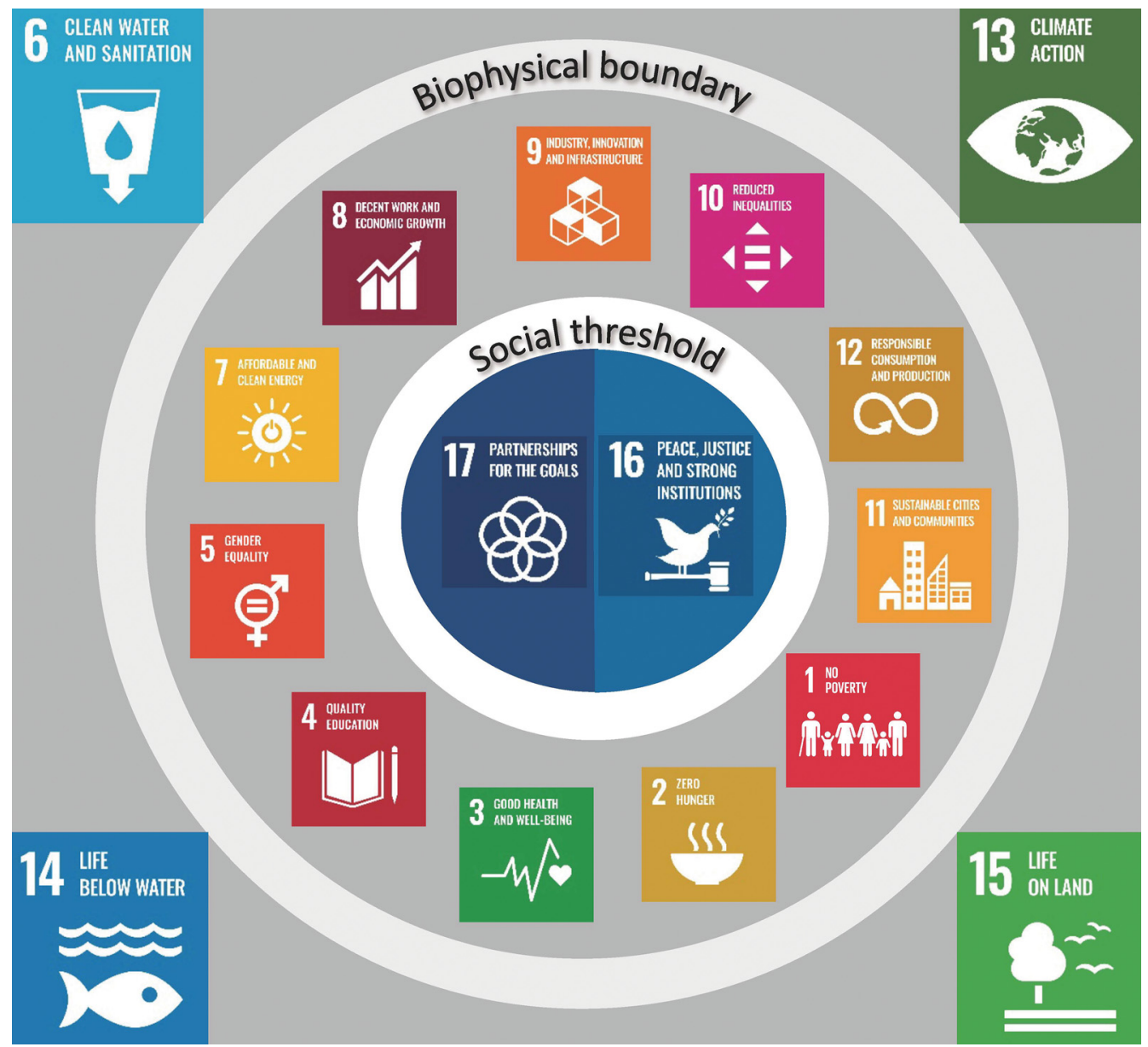

Fig. 5. The interdependency and relationships of the 17 UN Sustainable Development Goals (SDGss) (UN 2016, Diffenbaugh et al. 2020) organized by society (SDGs 1-5, 7, 11), economy $(8-10,12)$, and biosphere goals (SDGs 6, 13-15), integrated within 'the safe and just space for humanity' (in dark grey) according to the Doughnut Economics framework (Raworth 2017). The biosphere SDGs represent the 'biophysical boundaries' of the doughnut, while peaceful, just and inclusive societies with strong institutions and global partnerships for sustainable development (SDGs 16, 17) represent the 'social thresholds' needed for the human socio-economic space to thrive

Targets will not be met. Specifically, Target 11 (about achieving a $10 \%$ of coastal and marine areas that are well protected) and Target 6 (about achieving sustainable fisheries and harvesting in marine and aquatic ecosystems) will be largely missed in many regions of the ocean.

\section{MARINE ECOLOGISTS AS KEY ACTORS OF CHANGE}

Many of the new international initiatives that aim to shape human societies for a sustainable future are, at least in part, based on scientific advice. Ecological, societal and political lessons learnt during the COVID-19 pandemic have highlighted that new poli- cies should be primarily based on the best available science (Pearson et al. 2020). A recognition of this role of science for policy brings a unique opportunity to marine scientists in general, and marine ecologists in particular, who can contribute to achieving sustainable ocean use and set efficient and effective goals within the UN SDG context (Claudet et al. 2020, Friedman et al. 2020) (Fig. 5).

The relationships between marine living organisms, including humans, and their shared physical environment lie at the core of the discipline of marine ecology, which seeks to understand the vital connections between organisms and the world around them (Kaiser et al. 2011, Borja et al. 2020). Ecologists' pursuit of a systemic understanding of the diversity of life, including trait and functional diversity, the pro- 
cesses that maintain it, and the impacts that affect it, can play an essential role in turning the current multi-faceted crisis into an opportunity. Marine ecologists can be key actors to find real-world solutions towards balancing conservation with the use of marine ecosystems while integrating the health of the natural ecosystems and humans and considering their interconnectedness. Marine ecology as a diverse discipline has contributed essential knowledge needed to achieve a sustainable ocean, with information on the role of marine biodiversity and the key processes that maintain the functioning of marine ecosystems. Research to identify which system elements can maximise resilience, redundancy and resistance; how to set thresholds and directions of change for new societal targets within system thinking; and how to integrate the value of diverse ecosystem services that sustain and benefit human societies are just some examples of potentially relevant contributions to redefining our relationship with nature (Borja et al. 2020).

However, large scientific and technological gaps remain regarding marine science, and the new decade to come presents a great opportunity to push the boundaries (European Marine Board 2019, Fulton et al. 2019, Friedman et al. 2020, Heymans et al. 2020). New hot topics related to the 4 dimensions (3D and temporal) of the ocean, the role of multiple stressors and of extreme events, and the future impact of invasive species remain to be fully investigated, and ocean technologies, data collection, modelling and the new analytical capabilities of artificial intelligence need to be fully developed to achieve a more sustainable use of the ocean (European Marine Board 2019).

In the context of the COVID-19 pandemic and the urgency to act, there are several key topics where marine ecologists can offer a crucial contribution. These include the following:

First, embrace complexity and interdependency of the socio-ecological systems. Marine ecologists are uniquely positioned to develop their science, acknowledging the complexity of the socio-ecological reality of the oceans, where many species interact, where multiple and cumulative activities of humans can have an impact, and where the dynamics between land-ocean-atmospheric processes have an increasing relevance (Claudet et al. 2020, Katsanevakis et al. 2020). This implies that, aside from highly specialised studies that are essential to increasing the depth of scientific topics, marine scientists need to bridge disciplines and methods, create dialogues with complementary views, and incorporate the voice of multiple stakeholders into integrated assessments (Fulton et al. 2015, Katsanevakis et al. 2020).

Second, move from quantifying problems to evaluating solutions. Marine scientists have thoroughly documented the degradation of the oceans, and large efforts have been put into identifying drivers of change, looking both back and into the future. In the next decade, research will need to focus as well on identifying solutions and quantifying options for prevention, mitigation, adaptation and transformation of harmful human activities. Rigorous studies that explore plausible trajectories of change using scenarios and counterfactual outcomes of climate change effects, and identify possible pathways to ensure sustainability, are urgently needed to inform policy and management. The identification and distillation of key aspects of scalable real-world applications of ocean-based solutions will become essential information in future scientific studies (Duarte et al. 2020), while risk assessments and uncertainty analyses should be the bone of such future work (Stelzenmüller et al. 2020).

Third, make scientific outputs operational. New contributions of marine science that prioritise operational solutions to urgent environmental problems and the fair use of the ocean are a high priority (Gattuso et al. 2018). Technological developments that allow screening, processing and integrating large amounts of information, and methodologies and applications that efficiently contribute to protect, mitigate, recover, restore and sustainably use the natural capital are real needs.

Fourth, prioritise communicating and sharing scientific knowledge. The (marine) scientific community has the moral obligation to make scientific data and products fully available to promote global collaborations and ensure open access to knowledge. Open Access should become a widely applied practice in marine sciences. Communication of scientific achievements, failures and unknowns is key to involve society in future transformations, and as such, this activity should become a priority for marine scientists and their institutions (e.g. Steenbeek et al. 2020). Communicating positive outcomes of successful use of the oceans and promoting ocean literacy can popularise the realisation that a healthy and sustainable ocean is desirable, possible and feasible, with wide benefits to societies that can willingly push for a much needed collective behavioural change (Bearzi 2020).

Acknowledgements. I would like to thank 2 reviewers and Dr Giovanni Bearzi for constructive and useful comments on previous versions of the paper. I would like to acknowledge Jeroen Steenbeek for his help with editing the text. 


\section{LITERATURE CITED}

Bates AE, Primack RB, Moraga P, Duarte CM (2020) COVID-19 pandemic and associated lockdown as a 'Global Human Confinement Experiment' to investigate biodiversity conservation. Biol Conserv 248:108665

Bearzi G (2020) Marine biology on a violated planet: from science to conscience. Ethics Sci Environ Polit 20:1-13

Borja A, Andersen JH, Arvanitidis CD, Basset A and others (2020) Past and future grand challenges in marine ecosystem ecology. Front Mar Sci 7:362

Braga F, Scarpa GM, Brando VE, Manfè G, Zaggia L (2020) COVID-19 lockdown measures reveal human impact on water transparency in the Venice Lagoon. Sci Total Environ 736:139612

Buckley R (2020) Conservation implications of COVID19: effects via tourism and extractive industries. Biol Conserv 247:108640

Bundy A, Chuenpagdee R, Boldt JL, Camara ML and others (2017) Strong fisheries management and governance positively impact ecosystem status. Fish Fish 18:412-439

Canning-Clode J, Sepúlveda P, Almeida S, Monteiro J (2020) Will COVID-19 containment and treatment measures drive shifts in marine litter pollution? Front Mar Sci 7:691

Ceballos G, Ehrlich PR, Raven PH (2020) Vertebrates on the brink as indicators of biological annihilation and the sixth mass extinction. Proc Natl Acad Sci USA 117: 13596-13602

Claudet J, Bopp L, Cheung WW, Devillers R and others (2020) A roadmap for using the UN Decade of Ocean Science for Sustainable Development in support of science, policy, and action. One Earth 2:34-42

Cohen MJ (2020) Does the COVID-19 outbreak mark the onset of a sustainable consumption transition? Sustain Sci Pract Pol 16:1-3

Coll M, Libralato S, Pitcher T, Solidoro C, Tudela S (2013) Sustainability implications of honouring the code of conduct for responsible fisheries. Glob Environ Change 23:157-166

Coll M, Steenbeek J, Pennino GM, Buszowski J and others (2020) Advancing global ecological modelling capabilities to simulate future trajectories of change in marine ecosystems. Front Mari Sci 7:567877

Corlett RT, Primack RB, Devictor V, Maas B and others (2020) Impacts of the coronavirus pandemic on biodiversity conservation. Biol Conserv 246:108571

Costello C, Ovando D, Hilborn R, Gaines SD, Deschenes O, Lester SE (2012) Status and solutions for the world's unassessed fisheries. Science 338:517-520

Cyranoski D (2020) Mystery deepens over animal source of coronavirus. Nature 579:18-19

* Dearing JA, Wang R, Zhang K, Dyke JG and others (2014) Safe and just operating spaces for regional social-ecological systems. Glob Environ Change 28:227-238

* Díaz S, Settele J, Brondízio ES, Ngo HT and others (2019) Pervasive human-driven decline of life on Earth points to the need for transformative change. Science 366(6471): eaax3100

Díaz S, Settele J, Brondízio E, Ngo H and others (2020) Summary for policymakers of the global assessment report on biodiversity and ecosystem services of the Intergovernmental Science-Policy Platform on Biodiversity and Ecosystem Services. IPBES, Bonn

Diffenbaugh NS, Field CB, Appel EA, Azevedo IL and others (2020) The COVID-19 lockdowns: a window into the
Earth System. Nat Rev Earth Environ 1:470-481

*Dodds WK, Perkin JS, Gerken JE (2013) Human impact on freshwater ecosystem services: a global perspective. Environ Sci Technol 47:9061-9068

Doughty CE, Prys-Jones TO, Faurby S, Abraham AJ and others (2020) Megafauna decline have reduced pathogen dispersal which may have increased emergent infectious diseases. Ecography 43:1107-1117

* Duarte CM, Agusti S, Barbier E, Britten GL and others (2020) Rebuilding marine life. Nature 580:39-51

* Estes JA, Terborgh J, Brashares JS, Power ME and others (2011) Trophic downgrading of planet earth. Science 333:301-306

EU (2008) Directive 2008/56/EC of the European Parliament and of the Council of 17 June 2008 establishing a framework for community action in the field of marine environmental policy (Marine Strategy Framework Directive). Off J Eur Union L 164:19-40

Euronews (2020) Will plastic pollution get worse after the COVID-19 pandemic? https://www.euronews.com/2020/ 05/12/will-plastic-pollution-get-worse-after-the-covid-19pandemic

European Marine Board (2019) Navigating the future V: marine science for a sustainable future. Position paper 24. European Marine Board, Ostend

European Parliament (2020) EU Shipping and ports facing coronavirus. https://www.europarl.europa.eu/RegData/ etudes/ATAG/2020/651907/EPRS_ATA(2020)651907_EN. pdf

FAO (2020a) How is COVID-19 affecting the fisheries and aquaculture food systems? FAO, Rome

FAO (2020b) The state of world fisheries and aquaculture. FAO, Rome

F Free CM, Thorson JT, Pinsky ML, Oken KL, Wiedenmann J, Jensen OP (2019) Impacts of historical warming on marine fisheries production. Science 363:979-983

Freire-González J, Font Vivanco D (2020) Pandemics and the environmental rebound effect: reflections from COVID19. Environ Resour Econ 76:462-465

Friedman WR, Halpern BS, McLeod E, Beck MW and others (2020) Research priorities for achieving healthy marine ecosystems and human communities in a changing climate. Front Mar Sci 7:5

Fulton EA, Boschetti F, Sporcic M, Jones T and others (2015) A multi-model approach to engaging stakeholder and modellers in complex environmental problems. Environ Sci Policy 48:44-56

F Fulton B, Blanchard J, Melbourne-Thomas J, Plagányi EE, Tulloch VJD (2019) Where the ecological gaps remain, a modelers' perspective. Front Ecol Evol 7:424

FWC (2020) Manatee mortality statistics. https://myfwc.com/ research/manatee/rescue-mortality-response/statistics/ mortality

* Gardner C (2020) Nature's comeback? No, the coronavirus pandemic threatens the world's wildlife. The Conversation. https://theconversation.com/natures-comeback-nothe-coronavirus-pandemic-threatens-the-worlds-wildlife136209

Gattuso JP, Magnan AK, Bopp L, Cheung WW and others (2018) Ocean solutions to address climate change and its effects on marine ecosystems. Front Mar Sci 5:337

Global Fishing Watch (2020) The effects of COVID-19 on global fishing activity. https://globalfishingwatch.org/ data-blog/global-fisheries-during-covid-19

Griggs D, Stafford-Smith M, Gaffney O, Rockström J and 
others (2013) Sustainable development goals for people and planet. Nature 495:305-307

Halpern BS, Walbridge S, Selkoe KA, Kappel CV and others (2008) A global map of human impact on marine ecosystems. Science 319:948-952

Halpern BS, Longo C, Hardy D, McLeod KL and others (2012) An index to assess the health and benefits of the global ocean. Nature 488:615-620

*Halpern BS, Frazier M, Potapenko J, Casey KS and others (2015) Spatial and temporal changes in cumulative human impacts on the world's ocean. Nat Commun 6:7615

Halpern BS, Frazier M, Afflerbach J, Lowndes JS and others (2019) Recent pace of change in human impact on the world's ocean. Sci Rep 9:11609

Heymans JJ, Bundy A, Christensen V, Coll M and others (2020) The Ocean Decade: A true ecosystem modeling challenge. Front Mar Sci 7:766

Huong NQ, Nga NTT, Van Long N, Luu BD and others (2020) Coronavirus testing indicates transmission risk increases along wildlife supply chains for human consumption in Viet Nam, 2013-2014. PLOS ONE 15:e0237129

IPCC (2018) Global warming of $1.5^{\circ} \mathrm{C}$ : an IPCC special report on the impacts of global warming of $1.5^{\circ} \mathrm{C}$ above pre-industrial levels and related global greenhouse gas emission pathways, in the context of strengthening the global response to the threat of climate change, sustainable development, and efforts to eradicate poverty. Masson-Delmotte V, Zhai P, Pörtner HO, Roberts D and others (eds). Intergovernmental Panel on Climate Change, Cambridge

IPCC (2019) IPCC special report on the ocean and cryosphere in a changing climate. Pörtner HO, Roberts DC, Masson-Delmotte V, Zhai P and others (eds). Intergovernmental Panel on Climate Change, Cambridge

Kaiser MJ, Attrill MJ, Jennings S, Thomas DN, Barnes DK (2011) Marine ecology: processes, systems, and impacts. Oxford University Press, New York, NY

Katsanevakis S, Coll M, Fraschetti S, Giakoumi S and others (2020) Twelve recommendations for advancing marine conservation in European and contiguous seas. Front Mar Sci 7:565968

Klemeš JJ, Van Fan Y, Tan RR, Jiang P (2020) Minimising the present and future plastic waste, energy and environmental footprints related to COVID-19. Renew Sustain Energy Rev 127:109883

Knight CJ, Burnham TL, Mansfield EJ, Crowder LB, Micheli F (2020) COVID-19 reveals vulnerability of small-scale fisheries to global market systems. Lancet Planet Health $4: \mathrm{e} 219$

Krausmann F, Erb KH, Gingrich S, Haberl H and others (2013) Global human appropriation of net primary production doubled in the 20th century. Proc Natl Acad Sci USA 110:10324-10329

* Le Quéré C, Jackson RB, Jones MW, Smith AJ and others (2020) Temporary reduction in daily global $\mathrm{CO}_{2}$ emissions during the COVID-19 forced confinement. Nat Clim Chang 10:647-653

Leach M, Raworth K, Röckstrom J (2013) Between social and planetary boundaries: Navigating pathways in the safe and just space for humanity. In: ISSC/UNESCO World Social Science Report 2013: Changing Global Environments. OECD/UNESCO Publishing, Paris

Levin LA, Le Bris N (2015) The deep ocean under climate change. Science 350:766-768
Lewis SL, Maslin MA (2015) Defining the anthropocene. Nature 519:171-180

Lotze HK, Lenihan HS, Bourque BJ, Bradbury RH and others (2006) Depletion, degradation, and recovery potential of estuaries and coastal seas. Science 312:1806-1809

* Lotze HK, Coll M, Magera MA, Ward-Paige C, Airoldi L (2011) Recovery of marine animal populations and ecosystems. Trends Ecol Evol 26:595-605

K Lotze HK, Tittensor DP, Bryndum-Buchholz A, Eddy TD and others (2019) Global ensemble projections reveal trophic amplification of ocean biomass declines with climate change. Proc Nat Acad Sci USA 116:12907-12912

K Lyons PC, Okuda K, Hamilton MT, Hinton TG, Beasley JC (2020) Rewilding of Fukushima's human evacuation zone. Front Ecol Environ 18:127-134

Maas B, Grogan KE, Chirango Y, Harris N and others (2020) Academic leaders must support inclusive scientific communities during COVID-19. Nat Ecol Evol 4:997-998

Main D (2020) Wildlife abounds in these places abandoned years before coronavirus: Studies of Korea's DMZ and exclusion zones around the Chernobyl and Fukushima Daiichi nuclear plants show how animals respond when humans flee. National Geographic https:// www.nationalgeographic.co.uk/animals/2020/05/wildlifeabounds-these-places-abandoned-years-coronavirus

Manenti R, Mori E, Di Canio V, Mercurio S and others (2020) The good, the bad and the ugly of COVID-19 lockdown effects on wildlife conservation: insights from the first European locked down country. Biol Conserv 249:108728

* McCauley DJ, Pinsky ML, Palumbi SR, Estes JA, Joyce FH, Warner RR (2015) Marine defaunation: animal loss in the global ocean. Science 347:1255641

*Mengerink KJ, Van Dover C, Ardron J, Baker M and others (2014) A call for deep-ocean stewardship. Science 344: 696-698

*Mongabay (2020) As COVID-19 batters fishery, Indonesia's sharks get a respite. https://news.mongabay.com/2020/ 05/as-covid-19-response-batters-sales-indonesias-sharkfishery-gets-a-respite/

* Mora C, Myers RA, Coll M, Libralato S and others (2009) Management effectiveness of the world's marine fisheries. PLOS Biol 7:e1000131

O'Neill DW (2020) Beyond green growth. Nature Sustainability 3:260-261

* O'Neill DW, Fanning AL, Lamb WF, Steinberger JK (2018) A good life for all within planetary boundaries. Nature Sustainability 1:88-95

Ortega M, Mascarell Y (2020) The Spanish Mediterranean fishing sector and its market reaction to the ongoing Coronavirus crisis. Preliminary analysis. Fundacio ENT https://ent.cat/wp-content/uploads/2020/04/Coronavirusevolution1.pdf:36

* Otero I, Farrell KN, Pueyo S, Kallis G and others (2020) Biodiversity policy beyond economic growth. Conserv Lett 13:e12713

* Pardo JC, Ramon D, Stefanelli-Silva G, Elegbede I, Lima LS, Principe SC (2020) Advancing through the pandemic from the perspective of marine graduate researchers: challenges, solutions, and opportunities. Front Mar Sci 7:528

*Pauly D, Alder J, Bennett E, Christensen V, Tyedmers P, Watson R (2003) The future for fisheries. Science 302: 1359-1361

* Pearson RM, Sievers M, McClure EC, Turschwell MP, Connolly RM (2020) COVID-19 recovery can benefit biodiversity. Science 368:838-839 
Poloczanska ES, Brown CJ, Sydeman WJ, Kiessling W and others (2013) Global imprint of climate change on marine life. Nat Clim Chang 3:919-925

Ramírez F, Afán I, Davis LS, Chiaradia A (2017) Climate impacts on global hot spots of marine biodiversity. Sci Adv 3:e1601198

Raworth K (2017) Doughnut economics: seven ways to think like a 21st-century economist. Chelsea Green Publishing, London

Rockström J, Steffen W, Noone K, Persson $\AA$ and others (2009a) A safe operating space for humanity. Nature 461: $472-475$

Rockström J, Steffen W, Noone K, Persson A and others (2009b) Planetary boundaries: exploring the safe operating space for humanity. Ecol Soc 14:32

Rutz C, Loretto MC, Bates AE, Davidson SC and others (2020) COVID-19 lockdown allows researchers to quantify the effects of human activity on wildlife. Nat Ecol Evol 4:1156-1159

Saadat S, Rawtani D, Hussain CM (2020) Environmental perspective of COVID-19. Sci Total Environ 728: 138870

Sala OE, Chapin FS, Armesto JJ, Berlow E and others (2000) Biodiversity - Global biodiversity scenarios for the year 2100. Science 287:1770-1774

Schewe J, Elliott J, Francois L, Gosling SN and others (2019) State-of-the-art global models underestimate impacts from climate extremes. Nat Commun 10:1005

Smale DA, Wernberg T, Oliver EC, Thomsen M and others (2019) Marine heatwaves threaten global biodiversity and the provision of ecosystem services. Nat Clim Chang 9:306-312

Sokolow SH, Nova N, Pepin KM, Peel AJ and others (2019) Ecological interventions to prevent and manage zoonotic pathogen spillover. Philos Trans R Soc Lond B Biol Sci 374:20180342

Steenbeek J, Romagnoni G, Bentley JW, Heymans JJ and others (2020) Combining ecosystem modelling with serious gaming in support of transboundary maritime spatial planning. Ecol Soc 25:21

Stelzenmüller V, Coll M, Cormier R, Mazaris AD and others (2020) Operationalizing risk-based cumulative effect assessments in the marine environment. Sci Total Environ $724: 138118$

The Guardian (2020a) Lockdown has cut Britain's vibrations, seismologists find. https://www.theguardian.com/

Editorial responsibility: Giovanni Bearzi,

Cordenons, Italy science/2020/apr/06/lockdown-has-cut-britains-vibrations -seismologists-find

The Guardian (2020b) Rightwing thinktanks use fear of Covid-19 to fight bans on plastic bags. https://www. theguardian.com/environment/2020/mar/27/rightwing -thinktanks-use-fear-of-covid-19-to-fight-bans-on-plasticbags

The New York Times (2020) In coronavirus, industry sees chance to undo plastic bag bans. https://www.nytimes. com/2020/03/26/climate/plastic-bag-ban-virus.html

Tittensor DP, Walpole M, Hill SLL, Boyce DG and others (2014) A mid-term analysis of progress toward international biodiversity targets. Science 346:241-244

* Trisos CH, Merow C, Pigot AL (2020) The projected timing of abrupt ecological disruption from climate change. Nature 580:496-501

UN (2016) The Sustainable Development Goals Report. United Nations publication issued by the Department of Economic and Social Affairs (DESA), New York. http:// unstats.un.org/sdgs/

UN Environmental Programme (2019) Emissions Gap Report 2019. UNEP, Nairobi

Visbeck M, Kronfeld-Goharani U, Neumann B, Rickels W and others (2014) A sustainable development goal for the ocean and coasts: global ocean challenges benefit from regional initiatives supporting globally coordinated solutions. Mar Policy 49:87-89

WWF (World Economic Forum) (2020) The Global Risk Report 15th edn, 2020. World Economic Forum. https:// www.weforum.org/reports/the-global-risks-report-2020

WWei G (2020) Food safety issues related to wildlife have not been taken seriously from SARS to COVID-19. Environ Res 186:109605

*Worm B, Barbier EB, Beaumont N, Duffy JE and others (2006) Impacts of biodiversity loss on ocean ecosystem services. Science 314:787-790

WWF (2020) Impact of COVID-19 on Mediterranean fisheries. https://www.wwfmmi.org/what_we_do/fisheries/ transforming_small_scale_fisheries/impact_of_covid_on_ mediterranean_fisheries/

*Young TP, Schwartz MW (2019) The Decade on Ecosystem Restoration is an impetus to get it right. Conserv Sci Practice 1:e145

Z Zhang T, Wu Q, Zhang Z (2020) Probable pangolin origin of SARS-CoV-2 associated with the COVID-19 outbreak. Curr Biol 30:1346-1351.e2

Submitted: June 30, 2020; Accepted: September 15, 2020

Proofs received from author(s): December 6, 2020 